\title{
Effect of Metformin in Preventing Insulin-Mediated Proliferation of p53 and Liver Kinase B1 Mutant and Wild-Type Lung Cancer Cell Lines
}

\author{
${ }^{1}$ Seema Saraswathy, ${ }^{2}$ Kavita Sahai, ${ }^{3}$ Bishamber D Toora, ${ }^{4}$ Manu Krishnan
}

\begin{abstract}
Background: Lung cancer and diabetes mellitus (DM) are diseases of high occurrence worldwide. Increased incidence of lung cancer in DM patients is frequently observed. In this context, an insulin-sensitizing drug, metformin (biguanides) may have inhibitory effects on the proliferation of lung cancer cells.

Aim: The present study was aimed to evaluate the growth proliferation effect of insulin on nonsmall cell lung carcinoma (NSCLC) cell lines. It also proposed to assess the preventive role of metformin in insulin-mediated proliferation in p53 and liver kinase B1 (LKB1) mutant and wild-type cell lines.
\end{abstract}

Materials and methods: Two non small cell lung carcinoma cell lines, A549 and H1299 ( $p 53$ and LKB1 wild-type and mutant) were used to analyze the mitogenic role of insulin by incubating for 24 hours with human recombinant insulin at concentrations of $1 \mathrm{nM}$ to $10 \mu \mathrm{M}$ and followed by the addition of metformin (concentrations from $1 \mu \mathrm{M}$ to $50 \mathrm{mM}$ ) for 24 hours along with insulin (500nM for A549 and $1 \mu \mathrm{M}$ for $\mathrm{H} 1299)$. The proliferation was assessed by MTT dye reduction test.

Results: Both the cell lines exhibited a significant and dosedependent growth proliferation $(p<0.001)$ with different concentrations of insulin. This was effectively $(p<0.001)$ inhibited by metformin treatment for 24 hours. The maximum reduction in growth was $73 \%$ and $67 \%$ for $\mathrm{A} 549$ and $\mathrm{H} 1299$ respectively.

Conclusions: Insulin in high circulating concentrations can augment the growth proliferation of lung cancer cells. Metformin can inhibit this in a multifaceted way, wherein the mechanism of action is independent of p53 and liver kinase B1.

Clinical significance: Metformin could inhibit the insulinmediated proliferation of cells, and hence it may be considered for the new therapeutic policies for treatment of human NSCLC.

\footnotetext{
${ }^{1}$ Tutor, ${ }^{2} \mathrm{HOD}$ and Consultant, ${ }^{3}$ Professor and Head, ${ }^{4}$ Classified Specialist

${ }^{1,3}$ Department of Biochemistry, Army College of Medical Sciences, Delhi Cantonment, India

${ }^{2}$ Department of Lab Sciences and Molecular Medicinem Army Hospital (R\&R), Delhi Cantonment, India

${ }^{4}$ Department of Dental Research and Implantology, Institute of Nuclear Medicine and Allied Sciences (INMAS), Defence Research and Development Organization (DRDO), Delhi, India

Corresponding Author:Seema Saraswathy, Tutor, Department of Biochemistry, Army College of Medical Sciences, Delhi Cantonment, Phone: +919811342638, e-mail: seemasaraswathy09@gmail.com
}

Keywords: Diabetes mellitus (DM), Metformin, Lung cancer, Liver kinase B1, p53.

How to cite this article: Seema S, Sahai K, Toora BD, Krishnan M. Effect of Metformin in Preventing Insulin-Mediated Proliferation of p53 and Liver Kinase B1 Mutant and WildType Lung Cancer Cell Lines. Journal of Medical Academics 2018;1(1):35-42.

\section{Source of support: Nil}

Conflict of interest: None

\section{INTRODUCTION}

Diabetes mellitus (DM) and lung cancer have worldwide prevalence with high mortality rate. World Health Organization $(\mathrm{WHO})$ data highlight the increase in diabetes cases from 108 million in 1980 to 422 million in 2014. Both caused around 1.6 million deaths in 2015., Needless to mention; they are major public health issues, in terms of the enormous sufferings inflicted on patients as well as for the huge economic impact it poses to the health care systems.

The increased risk for lung cancer in diabetes patients has been an active area of research. Further, the prognosis of lung cancer has also been dismal in diabetes patients. Also, comorbidity with diabetes adversely affects the survival time of lung cancer. It can be a predictive factor for recurrence as well. ${ }^{3-5}$ Besides, both the conditions share common risk factors too: age, diet, alcohol, tobacco use, obesity and lack of physical activity. ${ }^{4}$ The propensity of diabetes patients to the initiation, propagation, and outcome of lung cancer is attributed to the molecular mechanisms related to the insulin resistance of the cell. ${ }^{6}$ Insulin resistance is the failure of the cells to act in response to the hormone insulin. Long-term hyperinsulinemia occurring secondary to the insulin resistance may enhance proliferative capacities of the cells. Also, it stimulates the synthesis of insulin growth factor-I (IGF-I) and insulin growth factor-II ((IGF-II)) reduces the level of IGF binding proteins. ${ }^{7}$ Paradoxically, and all these can contribute to a neoplastic-like effect of insulin in lung cancer. To make matters worse, smoking and other related factors invariably present in lung cancer patients add on to the insulin resistance. ${ }^{4}$ Figure 1 represents the factors of diabetes mellitus contributing to cancer progression. 


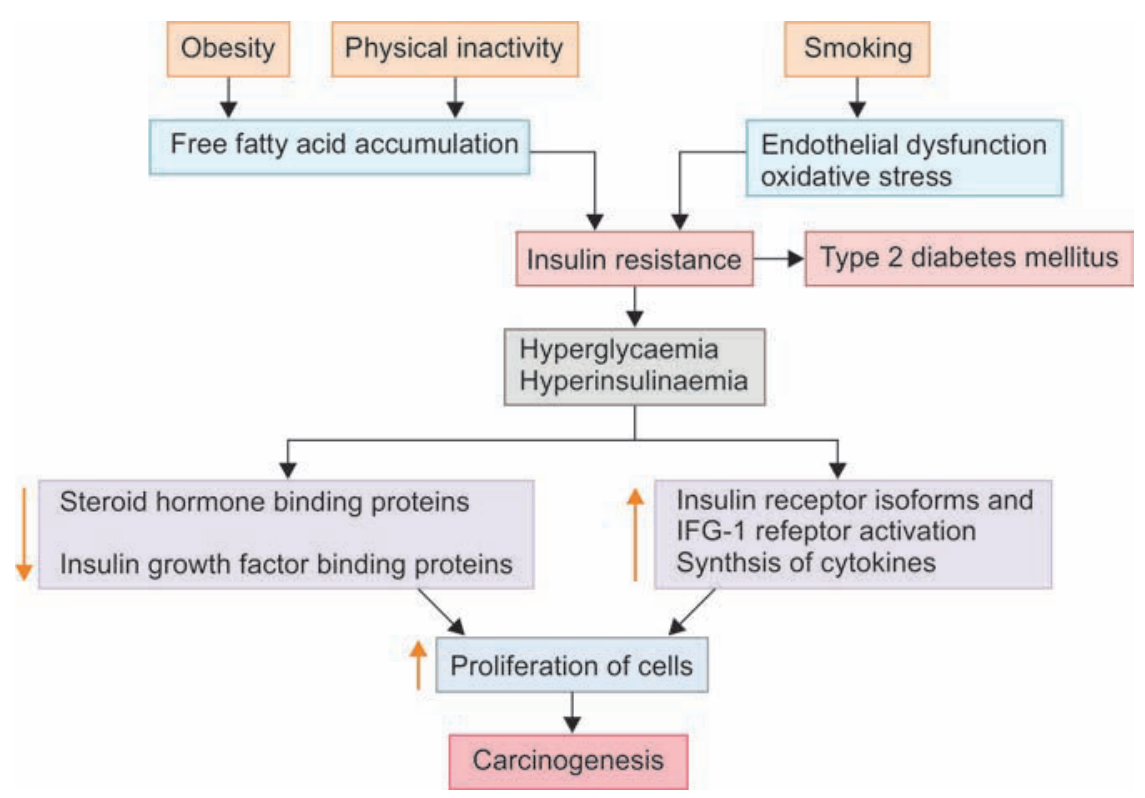

Fig. 1: Mechanisms contributing to cancer progression in diabetes mellitus

Hypoglycaemic drugs for DM mainly are insulin secretagogues (sulfonylureas), insulin sensitizers (biguanides, thiazolidinediones) and glucosidase inhibitors. The sulfonylureas have a direct effect on the $\beta$-cells of pancreatic islets for the release of insulin. This would also accelerate the proliferation of the cells. Contrary biguanides (metformin) increases the sensitivity of the cells to uptake glucose through various molecular mechanisms thereby reducing the circulating insulin. ${ }^{8}$ This, in turn, can prevent cell proliferation. In this perspective, metformin has an anti-cancerous therapeutic plain, which is not much explored. Therefore, irrespective of cancer types, the utility of metformin to this effect has been vigorously investigated. ${ }^{9}$ Singularly, or in combinations with other drugs, metformin has been cited for its antitumor activity. Yousef $\mathrm{M}$ et al. reviewed the in vitro/in vivo studies evaluating the antitumor effect of metformin and reported multiple targets of metformin action. ${ }^{10}$ Though it has experimented for many types of cancers, investigations focussing on insulin and metformin effects on lung cancer, have not been done so far. This makes the premise of the current research.

Metformin is extracted from the herb, Galega officinalis. At the molecular level, metformin activates adenosine monophosphate-regulated protein kinase (AMPK), with the rise in AMP: ATP ratio. This leads to decreased synthesis of protein and proliferation of cells by inhibiting the mammalian target of rapamycin (mTOR) pathway. ${ }^{11}$ Adenosine monophosphate binds to AMPK and produces a conformational change which phosphorylates its catalytic subunit which requires the involvement of LKB1, a tumor suppressor gene. Direct targeting of mTOR pathway independent of AMPK is also reported (Fig. 2). However, some studies mention the activation of

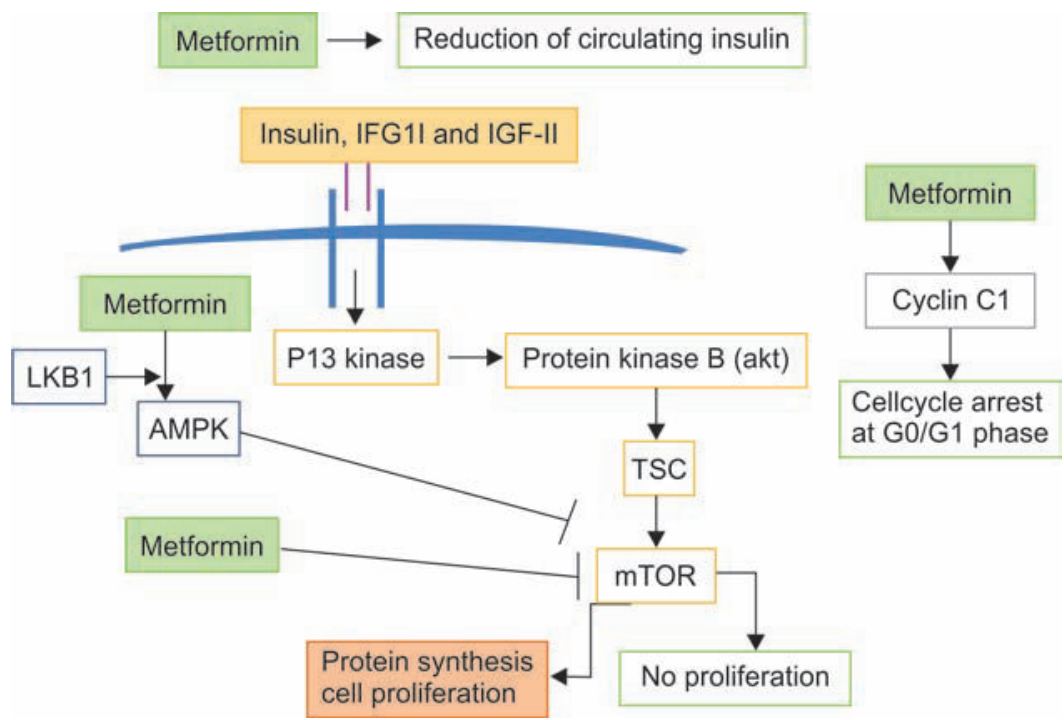

Fig. 2: Anti mitogenic roles of metformin 
AMPK pathway independent of LKB1. Moreover, another relevant issue regarding the targets of metformin is the mutation of the $p 53$ gene. Few experiments conclude the anti tumour effect of metformin is dependant of $p 53$ gene in terms of energy utilizing mechanisms in the cells. However, p53 independent action of metformin also has been cited. ${ }^{12,13}$

From the foregoing, the increasing incidence of lung cancer in diabetes patients may be attributed to the mitogenic role of insulin, which is usually seen in high circulating levels in the early phases of the disease. This effect may be reduced by insulin-sensitizing drugs like metformin. To have a precise understanding on this aspect of metformin, in the backdrop of its interaction with AMPK, LKB1 and p53, response of this drug with a lung cancer cell line was contemplated. So, the present in vitro study aimed to evaluate the effect of metformin on the insulin-mediated proliferation of two nonsmall cell lung carcinoma cell lines A549 (p53 wild-type and LKB1 mutated) and H1299 (p53 mutated and LKB1 wild-type).

\section{MATERIALS AND METHODS}

\section{Lung Cancer Cell Lines}

Human non-small cell lung cancer cell lines used for the experiment were A549 and H1299. The A549 is an alveolar adenocarcinoma cell line. They are $p 53$ wild-type and LKB1 mutated. ${ }^{11} \mathrm{H} 1299$ is non-small cell lung carcinoma cell line derived from the metastatic site of the lymph node. They have a homozygous partial deletion of $p 53$ gene, but it is LKB1 wild type.

Both the cell lines, A549, and H1299 were obtained from National Centre for Cell Sciences, Pune. The cell lines were transported in nutrient medium with $5 \%$ fetal bovine serum (FBS) and were maintained in Dulbecco's modified eagle's medium, high glucose, $4.5 \mathrm{gm} / \mathrm{L}$ (DMEM) (Gibco, Invitrogen) supplemented with $10 \%$ heat-inactivated FBS, $1 \%$ solution of penicillin (5000 units $/ \mathrm{mL})$ and streptomycin $(500 \mu \mathrm{g} / \mathrm{mL})$. The incubation was done at $37^{\circ} \mathrm{C}$ and $5 \% \mathrm{CO}_{2}$ and saturating humidity. The medium was renewed at every 2 to 3 days for both the cell lines. When growth attained 60 to $70 \%$ confluent, the subculturing was done. The morphology of the cells is shown in Fig. 3.

\section{Viability Staining}

The staining technique for assessing the viability is based on the dye exclusion method. The cells with intact membrane are unable to take up the dye and are considered viable; whereas, the dye enters nonviable cells and stain the color of the dye. The dye used here was $0.5 \%$ trypan blue prepared in phosphate buffered saline. The equal volume of the dye and the cell suspension were mixed and allowed to stand for 1 to 2 minutes. This mixture was charged to the counting chamber, and the cells which stained blue were counted as nonviable and nonstained were considered as viable.

\section{Insulin and Metformin Treatment}

The cell count was performed by hemocytometry, and the viability was assessed by trypan blue staining test. Approximately, 10,000 cells of A549 and H1299 were seeded with complete growth medium in 96 well plates (Tarsson, India) and incubated at $37^{\circ} \mathrm{C}$ and $5 \% \mathrm{CO}_{2}$ for 24 hours for adherence of the cells on to the surface. Growth medium without FBS was added to each well to synchronize the cell cycle dividing phase. Human recombinant insulin $(10 \mathrm{mg} / \mathrm{mL}$, High media, Mumbai, India) was diluted with the FBS free growth media to various doses like $1 \mathrm{nM}$ to $10 \mu \mathrm{M}$. Each concentration of insulin was added to the cells along with growth media free from FBS and incubated for 24 hours. Cells without insulin were treated as negative control.

Similarly approximately, 10,000 cells were seeded on to the 96 well plates for finding the inhibitory effect of

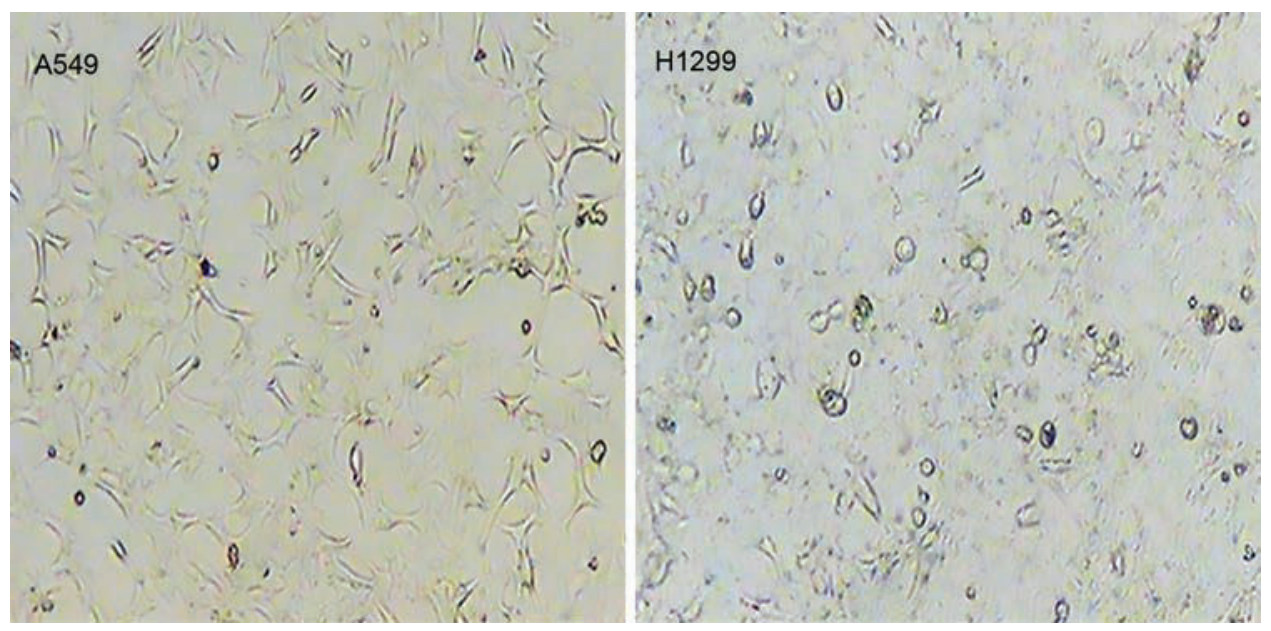

Fig. 3: Morphology of non small cell lung cancer cell lines, A549 and H1299 
metformin. Metformin hydrochloride (Ranbaxy India) was prepared at various concentrations by dissolving in sterile water. The concentrations used were, $1 \mu \mathrm{M}$ to $50 \mathrm{mM}$. Each cell line was given treatment with varying concentration of metformin along with the submaximal concentration of insulin showing proliferation. The cells were incubated for 24 hours. The experiment was conducted in triplicates.

\section{MTT Dye Reduction Test}

The proliferation of cells was evaluated by MTT assay. This uses the yellow tetrazolium salt, MTT (3-(4, 5-Dimethylthiazol-2-yl)-2, 5-diphenyltetrazolium bromide) and reduction of which takes place in the mitochondria of the living cells by succinic dehydrogenase with the formation of purple formazan crystals. The formazan conversion is directly proportional to the number of viable cells. After the insulin and metformin treatment, the cells were added with 200ul of MTT solution $(50 \mathrm{mg} \% \mathrm{w} / \mathrm{v}$ ) and incubated for 3-4 hours followed

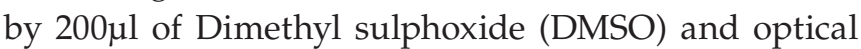
density is measured at $492 \mathrm{~nm}$ with a reference filter at $620 \mathrm{~nm}$ in microplate reader (LMR 9602 G, Indian Scientific, India). The mean percentage of survival of cells was calculated.

\section{Data Analysis}

Mitogenic effect of insulin and the percentage of survival of cells after metformin treatment were analyzed for significance by one way analysis of variance (ANOVA). Duncan's multiple range test were used for multiple comparisons. The effect of cell lines at various concentrations of insulin and metformin were compared by two way ANOVA. The level of significance accepted was at $p<0.05$.

\section{RESULTS}

\section{Mitogenic Effect of Insulin on A549 and H1299}

Statistically significant growth proliferation (One way ANOVA, $p<0.001)$ was noticed for various concentrations of insulin on lung cancer cell lines, A549, and H1299 as shown in Table 1. There was no significant proliferation for lower concentrations for the two cell lines. Approximately 2 and 1.69 fold increase in proliferation was obtained with $1 \mu \mathrm{M}$ of insulin for A549 and H1299. Further increase in insulin concentration did not enhance the growth; instead, it reached a plateau for the two cell lines. The proliferation of cells was in a dose-dependent manner (Fig. 4).

\section{Effect of Metformin on A549 Cell Line and H1299}

The submaximal concentration of insulin $500 \mathrm{nM}$ and $1 \mu \mathrm{M}$ was used for proliferation analysis along with
Table 1: One way ANOVA of percentage survival of A549 and H1299 cells following treatment with Insulin

\begin{tabular}{lll}
\hline $\begin{array}{l}\text { Concentrations } \\
\text { of insulin }\end{array}$ & $\begin{array}{l}\text { Mean percentage } \\
\text { Survival (A549) }\end{array}$ & $\begin{array}{l}\text { Mean percentage } \\
\text { Survival }(\text { H1299) }\end{array}$ \\
\hline Negative Control & $100.25^{\mathrm{a}} \pm 4.27$ & $100.34^{\mathrm{a}} \pm 6.69$ \\
$1 \mathrm{nM}$ & $106.55^{\mathrm{a}} \pm 4.31$ & $106.39^{\mathrm{a}} \pm 5.46$ \\
$5 \mathrm{nM}$ & $108.92^{\mathrm{a}} \pm 4.32$ & $106.17^{\mathrm{a}} \pm 2.51$ \\
$10 \mathrm{nM}$ & $121.55^{\mathrm{b}} \pm 6.88$ & $116.75^{\mathrm{b}} \pm 8.75$ \\
$50 \mathrm{nM}$ & $129.07^{\mathrm{bc}} \pm 5.16$ & $119.60^{\mathrm{b}} \pm 5.32$ \\
$100 \mathrm{nM}$ & $137.34^{\mathrm{c}} \pm 9.41$ & $130.32^{\mathrm{c}} \pm 5.06$ \\
$500 \mathrm{nM}$ & $158.90^{\mathrm{d}} \pm 8.51$ & $143.05^{\mathrm{d}} \pm 6.76$ \\
$1 \mu \mathrm{M}$ & $203.76^{\mathrm{e}} \pm 6.89$ & $169.85^{\mathrm{e}} \pm 14.90$ \\
$5 \mu \mathrm{M}$ & $201.25^{\mathrm{e}} \pm 11.4$ & $178.56^{\mathrm{f}} \pm 4.96$ \\
$10 \mu \mathrm{M}$ & $199.50^{\mathrm{e}} \pm 13.3$ & $180.57^{\mathrm{f}} \pm 9.25$ \\
& p value $<0.001$ & p value $<0.001$ \\
\hline
\end{tabular}

$a, b, c, d, e, f-$ Means with same superscript within each cell line do not differ each other (Duncan's multiple range test)

metformin for A549 and H1299 cell lines respectively. Significant inhibition (One way ANOVA, $\mathrm{p}<0.001$ ) of proliferation was observed for cellular growth as shown in Table 2. For lower concentrations, no inhibitory effect is detected. Duncan's multiple range tests showed significant differences in percentage survival of cells between high concentrations of metformin. Maximum inhibition of $73 \%$ for A549 and $67 \%$ for H1299 was observed with metformin concentration $50 \mathrm{mM}$. The concentration at which $50 \%$ inhibition $\left(\mathrm{IC}_{50}\right)$ is found to be $9.98 \mathrm{mM}$ and $17.2 \mathrm{mM}$ by $\log$ transformed probit analysis for A549 and H1299 respectively. The inhibitions at various concentration of metformin showed a dose-dependent response (Fig. 5).

\section{Comparison of Effect of Insulin and Metformin between Two Cell Lines}

Effect of insulin on the growing proliferation and the effect of metformin between two cell lines were compared at all concentrations using two way ANOVA (Table 3 and

Table 2: Analysis of variance (One way ANOVA) of percentage survival of A 549 and H1299 cells following treatment with metformin

\begin{tabular}{lll}
\hline $\begin{array}{l}\text { Concentrations of } \\
\text { Metformin }\end{array}$ & $\begin{array}{l}\text { Mean percentage } \\
\text { Survival (A549) }\end{array}$ & $\begin{array}{l}\text { Mean percentage } \\
\text { Survival }(\text { H1299) }\end{array}$ \\
\hline Negative Control & $100.158^{\mathrm{g}} \pm 5.366$ & $99.903^{\mathrm{e}} \pm 6.407$ \\
$1 \mu \mathrm{M}$ & $98.104^{\mathrm{g}} \pm 2.349$ & $96.881^{\mathrm{e}} \pm 4.137$ \\
$5 \mu \mathrm{M}$ & $96.209^{\mathrm{fg}} \pm 6.567$ & $96.686^{\mathrm{e}} \pm 4.423$ \\
$10 \mu \mathrm{M}$ & $95.419^{\mathrm{ef}} \pm 3.797$ & $94.249^{\mathrm{e}} \pm 8.080$ \\
$50 \mu \mathrm{M}$ & $99.526^{\mathrm{g}} \pm 2.508$ & $94.737^{\mathrm{e}} \pm 5.226$ \\
$100 \mu \mathrm{M}$ & $92.575^{\mathrm{ef}} \pm 5.020$ & $96.784^{\mathrm{e}} \pm 7.083$ \\
$500 \mu \mathrm{M}$ & $91.153^{\mathrm{e}} \pm 2.516$ & $94.932^{\mathrm{e}} \pm 6.558$ \\
$1 \mathrm{mM}$ & $81.359^{\mathrm{d}} \pm 4.121$ & $88.499^{\mathrm{d}} \pm 2.637$ \\
$5 \mathrm{mM}$ & $58.926^{\mathrm{C}} \pm 4.969$ & $68.616^{\mathrm{C}} \pm 5.982$ \\
$10 \mathrm{mM}$ & $43.286^{\mathrm{b}} \pm 6.772$ & $52.534^{\mathrm{b}} \pm 5.306$ \\
$50 \mathrm{mM}$ & $27.172^{\mathrm{a}} \pm 2.38$ & $33.041^{\mathrm{a}} \pm 3.094$ \\
& p value $<0.001$ & p value $<0.001$ \\
\hline
\end{tabular}

$a, b, c, d, e, f, g$ - Means with same superscript within each cell line do not differ each other (Duncan's multiple range test) 

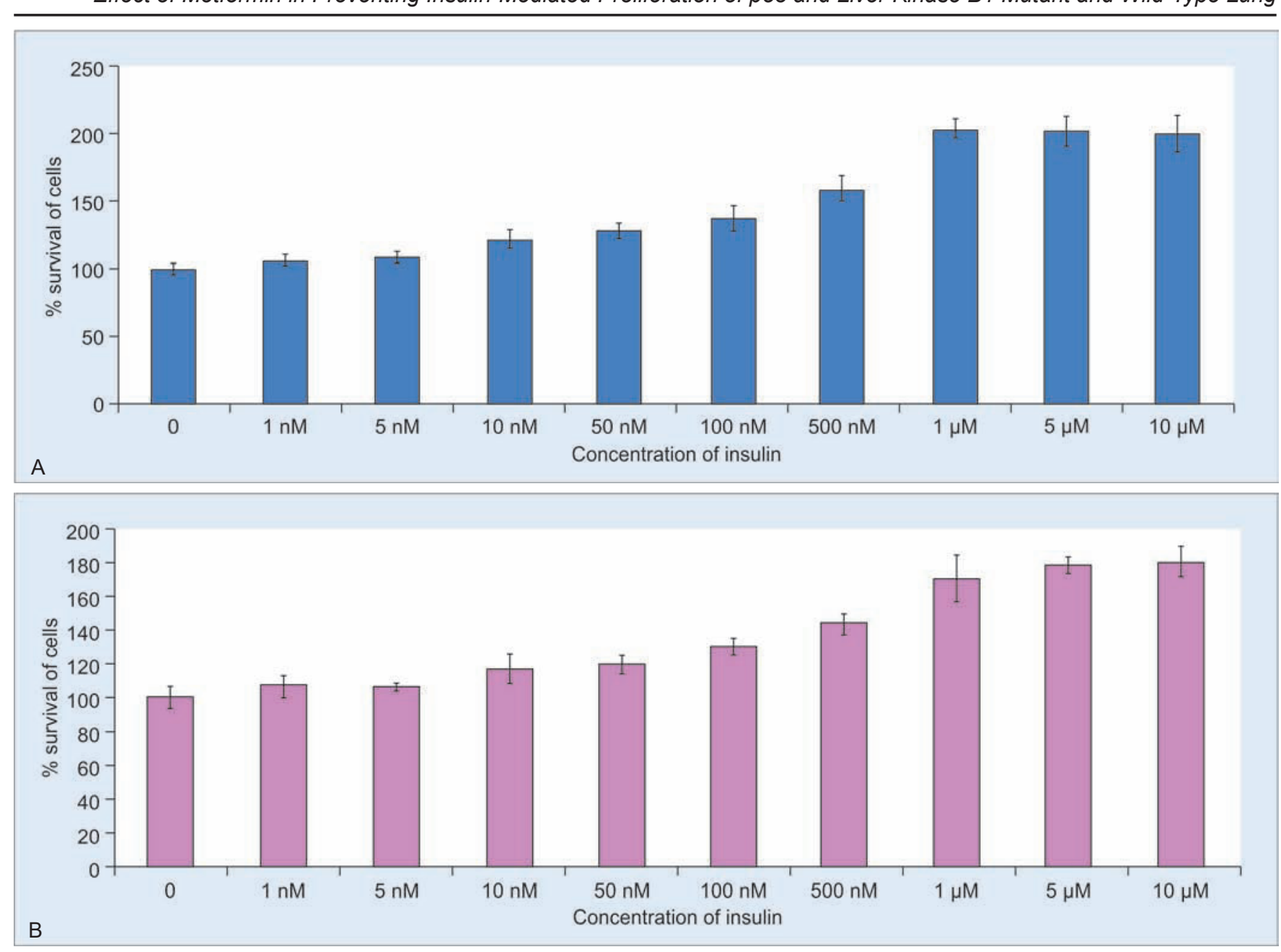

Fig. 4: Dose dependant effect of insulin on proliferation of A549 (A) and H1299 (B)

4). The dose-response pattern obtained was similar for both the cell lines. In growth proliferation by the treatment with insulin, significant differences between cell lines were not noticed for lower concentrations but were found to be significant in higher doses of insulin. Individually metformin showed a significant inhibitory effect on both the cell lines, the effect was more pronounced for A549 cell lines. Maximum of 73\% inhibition was seen with A549 which is LKB1 mutated, whereas a maximum of $67 \%$ was only observed for H1299 (p53 mutated). A lower concentration of metformin could inhibit proliferation of $50 \%$ of cells of A549 (9.98 mM) compared to H1299 (17.2 mM). The dose-dependent response was observed for both the cell lines upwards from concentration $1 \mathrm{mM}$. This is presented in Figure 6.

\section{DISCUSSION}

The increased incidence of cancer in DM type 2 patients is primarily due to the failure of expression of insulindependent glucose transporters on the surface of the cells which causes increasing circulating levels of glucose and insulin for a long duration. High insulin level in extracellular fluid exerts the proliferative effects on cells. According to the present study, insulin stimulated the growing proliferation of serum-starved nonsmall cell lung cancer (NSCLC) cell lines, A549, and H1299. These findings corroborate with the reports on the effect of insulin on lung cancer. ${ }^{14}$ Several studies were cited about the correlation of lung cancer incidence in diabetes. ${ }^{3-5}$ A549, a cell line of adenoma of alveoli showed a maximum of two fold increase in growth, whereas for $\mathrm{H} 1299$ cells the hike was 1.69 fold. Variation noticed in the proliferation percentage may be attributed to the differences in the expression of insulin and IGF receptors on cell surfaces. In an in vivo experiment, the risk of lung cancer with inhaled insulin was studied. ${ }^{15}$ The reduced survival of diabetic patients on insulin therapy was described in NSCLC patients and it adversely affected the prognosis too. ${ }^{16,17}$ Results of our in vitro study are well in conformity with the above-mentioned data which concluded that high concentrations of circulating insulin could be a risk factor for carcinogenesis.

In this study, both nonsmall cell lung carcinoma cell lines showed a significant growth inhibitory effect by metformin on the insulin-mediated proliferation. These results are in accordance with the in vitro study conducted for A549 and the tobacco-induced carcinogenesis. ${ }^{18}$ The effect of metformin was investigated along 

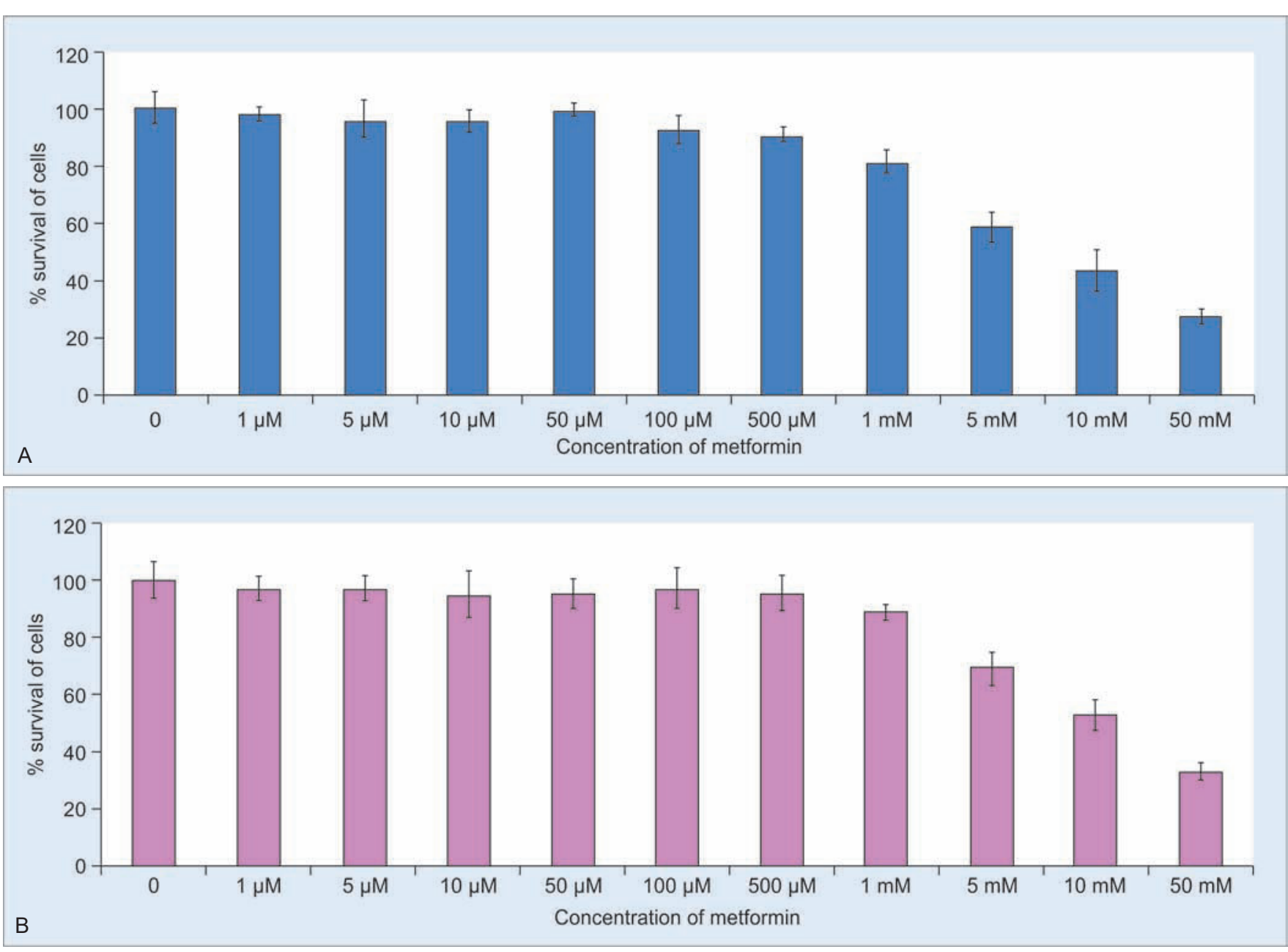

Fig. 5: Dose dependant effect of metformin on A549 (A) and H1299 (B)

with the chemotherapeutic agent, paclitaxel/cisplatin by using nonsmall cell lung carcinoma cell lines, A549.10 Many molecular mechanisms have been suggested for anticancer activity of metformin. Most generally cited mechanism is the activation AMPK, the indicator of cellular stress. In addition, Memmott et al. specify the inhibition of IGF and hybrid receptor phosphorylation, protein kinase $B$ and $m T O R$ in lung tissue without activating the AMPK pathway. ${ }^{18}$ Furthermore, metformin represses the mitotic elements like kinesins, tubulins, and histones. It

Table 3: Comparison of cell proliferation between two cell lines on treatment with insulin by Two Way ANOVA

\begin{tabular}{|c|c|c|c|c|c|}
\hline Source & $\begin{array}{l}\text { Type III Sum } \\
\text { of Squares }\end{array}$ & $d f$ & $\begin{array}{l}\text { Mean } \\
\text { Square }\end{array}$ & Fvalue & $P$ value \\
\hline $\begin{array}{l}\text { Corrected } \\
\text { Model }\end{array}$ & 193373.64 & 19 & 10177.56 & 161.81 & $<0.001$ \\
\hline Intercept & 3076780.02 & 1 & 3076780.02 & 48916.99 & $<0.001$ \\
\hline Group & 5202.64 & 1 & 5202.64 & 82.72 & $<0.001$ \\
\hline Treatment & 183597.19 & 9 & 20399.69 & 324.33 & $<0.001$ \\
\hline $\begin{array}{l}\text { Group X } \\
\text { Treatment }\end{array}$ & 4337.39 & 9 & 481.93 & 7.66 & $<0.001$ \\
\hline Error & 8554.13 & 136 & 62.90 & & \\
\hline Total & 3338847.39 & 156 & & & \\
\hline $\begin{array}{l}\text { Corrected } \\
\text { Total }\end{array}$ & 201927.77 & 155 & & & \\
\hline
\end{tabular}

induces cell cycle arrest at the $\mathrm{G}_{0} / \mathrm{G}_{1}$ phase and inhibits the proliferation of cells. ${ }^{10}$

In the current study, we compared the proliferation by insulin and inhibition by metformin on cell lines of p53 mutant and wild-type. A tumor suppressor gene, p53, has a wide range of functions like apoptosis, DNA repair and cell cycle arrest to prevent cancer progression. Both the p53 mutant and wild-type lung cancer cell lines were sensitive to insulin as well as metformin in a highly significant manner. This report is similar to the observation of Ben Sahra et al. which couldn't find any dissimilarity in metformin effect to $p 53$ mutant and wild-type breast and prostate cell lines. ${ }^{12}$ They interpret the inhibitory effects of metformin could be by arresting the cell cycle at $G_{0} / G_{1}$ phase independently of $p 53$. However, Buzzai et al. suggested that metformin could stimulate metabolic processes only in p53 wild-type cells. ${ }^{19}$ In glucose deprived cancer cells, p53 helps to arrest cell proliferation until the energy source is restored. This is not in accordance with our findings. This implies metformin may effectively block the molecular energy utilization through different mechanisms and prevents the mitogenic effect caused by insulin. 

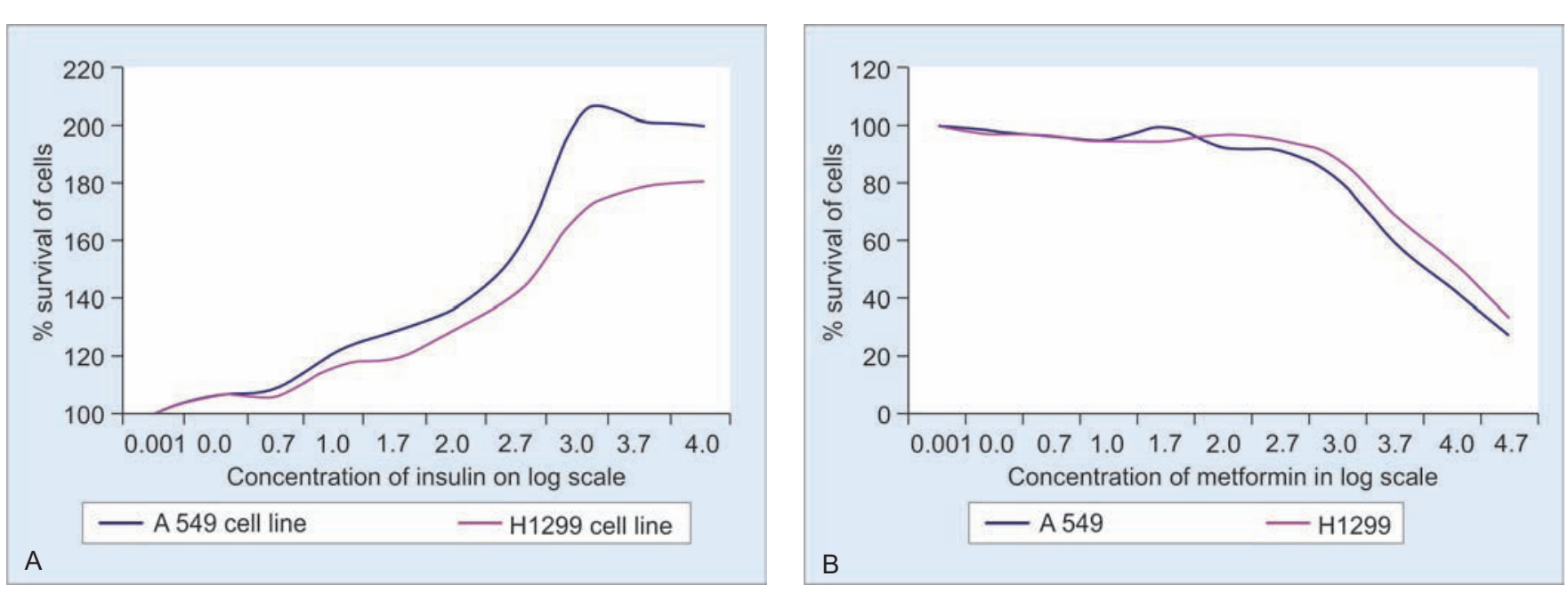

Fig. 6: Comparison of effect of insulin on growth proliferation (A) and effect of metformin (B) on A549 and H 1299

The specificity of metformin action in LKB1 mutated cells is another important point. Mainly lung cancer cell lines are LKB1 mutated. This tumor suppressor is involved in maintaining cellular integrity. Various reports suggest the requirement of LKB1for an effective growth reduction by metformin. The inhibition of cell growth was not detected in HeLa cells which have no allele for the LKBI gene. ${ }^{20}$ However, the cell lines selected in this study, LKB1 mutant (A549) and wild-type (H1299) showed a significant inhibitory effect even though variations exist in the percentage of inhibition. This is similar to the reports of Rocha et al. and Guo et al. ${ }^{21,22}$

The reports showed the anticancer role of metformin. Moreover, it compared the metformin effects in two nonsmall cell lung carcinoma cell lines which are the mutant and wild type of $p 53$ and LKB1. Though diverse reports regarding the involvement of these genes in metformin mechanism exist, this in vitro study demonstrated significant inhibition of insulin-mediated proliferation for both the cell lines.

Table 4: Comparison of percentage survival between two cell lines at different concentrations of metformin by Two Way ANOVA

\begin{tabular}{|c|c|c|c|c|c|}
\hline Source & $\begin{array}{l}\text { Type III } \\
\text { sum of } \\
\text { squares }\end{array}$ & $d f$ & $\begin{array}{l}\text { Mean } \\
\text { square }\end{array}$ & $F$ value & $p$ value \\
\hline $\begin{array}{l}\text { Corrected } \\
\text { Model }\end{array}$ & 91626.32 & 21 & 4363.16 & 169.33 & $<0.001$ \\
\hline Intercept & 1179160.98 & 1 & 1179160.98 & 45762.44 & $<0.001$ \\
\hline Group & 395.42 & 1 & 395.42 & 15.35 & $<0.001$ \\
\hline Treatment & 90334.55 & 10 & 9033.46 & 350.58 & $<0.001$ \\
\hline $\begin{array}{l}\text { Group X } \\
\text { Treatment }\end{array}$ & 896.36 & 10 & 89.64 & 3.48 & $<0.001$ \\
\hline Error & 3968.12 & 154 & 25.77 & & \\
\hline Total & 1274755.43 & 176 & & & \\
\hline $\begin{array}{l}\text { Corrected } \\
\text { Total }\end{array}$ & 95594.44 & 175 & & & \\
\hline
\end{tabular}

\section{CONCLUSION}

The present study confirms that hyperinsulinemia can contribute to the lung carcinogenesis and metformin could effectively prevent this process of proliferation from $1 \mathrm{mM}$ concentration. The antiproliferative or antimitotic activity of metformin, on lung cancer, is independent of p53 and LKB1 mutation. More receptor-based studies are necessary to elucidate the specific mechanism involved in the metformin activity. The usefulness of metformin in the treatment for premalignant stages of cancer progression, either individually or in combination with other modalities of cancer therapeutics needs to be studied in detail.

\section{CLINICAL SIGNIFICANCE}

The in vitro study could prove the inhibitory properties of metformin on the insulin-mediated proliferation of nonsmall cell lung cancer cell lines. Hence it may be considered to include metformin for treatment of human NSCLC or its premalignant stages.

\section{REFERENCES}

1. World Health Organization. Diabetes facts sheets [Internet]. Geneva: World Health Organization; 15 Nov 2017. Available from http://www.who.int/en/news-room/fact-sheets/ detail/diabetes.

2. World Health Organization. Cancer facts sheets [Internet]. Geneva: World Health Organization; 1 Feb 2018. Available from http://www.who.int/en/news-room/fact-sheets/ detail/cancer.

3. Zhu L, Cao H, Zhang T, Shen H, Dong W, Wang L, et al. The effect of diabetes mellitus on lung cancer prognosis: A PRISMA-complaint meta analysis of cohort studies. Medicine (Baltimore). 2016 Apr; 95(17):e3528.

4. Giovannucci E, Harlan DM, Michael CA, Bergenstal RM, Gapstur SM, Laurel AH, et al. Diabetes and Cancer. Diabetes Care. 2010 Jul;33(7):1674-168.

5. Kurushima K, Watanabe H, Ishikawa H, Satoh H, Hizawa N. Survoval of patients with lung cancer and diabetes mellitus. Mol Clin Oncol. 2017 Jun;6(6):907-910. 
6. Park SM, Lim MK, Shin SA, Yun YH. Impact of prediagnosis smoking, alcohol, obesity, and insulin resistance on survival in male cancer patients: National Health Insurance Corporation Study. J Clin Oncol. 2006 Nov; 24(31): 5017-5024.

7. Pollak M. Insulin and insulin-like growth factor signalling in neoplasia. Nat Rev Cancer. 2008 Dec; 8(12): 915-928.

8. Bosenberg LH,van Zyl DG. The mechanism of action of oral antidiabetic drugs: A review of recent literature. JEMDSA. 2008 Dec; 13(3): 80-88.

9. Andujar-Plata P, Pi-Sunyer X, Laferrere B. Metformin effects revisited. Diabetes Res Clin Pract. 2012 Jan; 95(1): 1-9.

10. Yousef M, Tsiani E. Metformin in lung cancer: Review of in viro and in vivo animal studies. Cancers. 2017 May ; 9(5): E45.

11. Landman GW, KleefstraN, van Hateren KJ, Groenier $\mathrm{KH}$, Gans RO, Bilo HJ. Metformin associated with lower cancer mortality in type 2 diabetes: ZODIAC-16. Diabetes Care. 2010 Feb; 33(2): 322-326.

12. Ben Sahra I, Laurent K, Giuliano S, Larbret F, Ponzio G, Gounon P,et al. Targeting cancer cell metabolism: the combination of metformin and 2-deoxyglucose induces p53-dependent apoptosis in prostate cancer cells. Cancer Res. 2010 Mar; 70(6): 2465-2475.

13. Memmott RM, Dennis PA. LKB1 and mammalian target of rapamycin as predictive factors for the anticancer efficacy of metformin. J Clin Oncol. 2009 Dec; 27(34):226-227.

14. Argirion I, Weistein SJ, Mannisto S, Albanes D, Modu AM. Serum insulin, glucose, indices of insulin resistance and risk of lung cancer. Cancer Epidemio Biomarkers Prev. 2017 Oct; 26(10): 1519-1524.
15. Mitri J, Pittas AG. Inhaled insulin--what went wrong. Nat Clin Pract Endocrinol Metab. 2009 Jan;5(1):24-25.

16. Farhan SY, Jankowski M, Hanbali A, Wang D. The use of insulin and the effect on survival of non-small cell lung cancer patients. Paper presented at the 2009 ASCO Annual Meeting Orlando, Florida.

17. Kurishima $\mathrm{K}$, Watanabe $\mathrm{H}$, Ishikawa $\mathrm{H}$, Satoh $\mathrm{H}$, Hizawa $\mathrm{N}$. Survival of patients with lung cancer and diabetes mellitus. Mol Clin Oncol. 2017 Jun;6(6):907-910.

18. Memmott RM, Mercado JR, Maier CR, Kawabata S, Fox SD, Dennis PA. Metformin prevents tobacco carcinogen--induced lung tumorigenesis. Cancer Prev Res (Phila). 2010 Sept; 3(9): 1066-1076.

19. Buzzai M, Jones RG, Amaravadi RK, Lum JJ, DeBerardinis RJ, Zhao F, et al. Systemic treatment with the antidiabetic drug metformin selectively impairs p53-deficient tumor cell growth. Cancer Res. 2007 Jul;67(14):6745-675229.

20. Zakikhani M, Dowling R, Frantus IG, Sonenberg N, Pollak MN. Metformin is an AMP kinase- dependent growth inhibitor for breast cancer cells. Cancer Res. 2006 Nov; 66(21): 10269-73.

21. Granja S, Marchiq I, Le Floch R, Moura CS, Baltazar F, Pouyssegur J. Disruption of BASIGIN decreases lactic acid export and sensitizes non-small cell lung cancer to biguanides independently of the LKB1 status. Oncotarget. 2015 Mar; 6(9): 6708-6721.

22. Guo Q, Liu Z, Jiang L, Liu M, Ma J, Yang C, et al. Metformin inhibits growth of human non-small cell lung cancer cells via liver kinaseB-1-independent activation of adenosine monophosphate-activated protein kinase. Mol Med Rep. 2016 Mar; 13(3): 2590-6. 